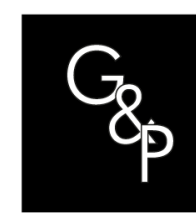

\title{
Lean System: analysis of scientific literature and identification of barriers for implementation from a bibliometric study
}

\author{
Sistema Lean: análise da literatura científica e identificação de \\ barreiras para implementação a partir de um estudo bibliométrico
}

\author{
Christiane Greijal Lobato ${ }^{1}$, Talita Mariane Cristino ${ }^{2}$ (1), Antônio Faria Neto², \\ Antônio Fernando Branco Costa ${ }^{3}$ \\ ${ }^{1}$ Universidade de Taubaté - UNITAU, Departamento de Engenharia Mecânica, Taubaté, SP, Brasil. \\ E-mail: lobatocg@gmail.com \\ ${ }^{2}$ Universidade Estadual Paulista - UNESP, Faculdade de Engenharia de Guaratinguetá, Departamento de \\ Engenharia Produção, Guaratinguetá, SP, Brasil. E-mails: talitamaryane@hotmail.com; antfarianeto@gmail.com \\ ${ }^{3}$ Universidade Federal de Itajubá - UNIFEI, Instituto de Engenharia de Produção e Gestão - IEPG, Itajubá, MG, \\ Brasil. E-mail: fbranco@unifei.edu.br
}

How to cite: Lobato, C. G., Cristino, T. M., Faria Neto, A., \& Costa, A. F. B. (2021). Lean System: analysis of scientific literature and identification of barriers for implementation from a bibliometric study. Gestão \& Produção, 28(1), e4769. https://doi.org/10.1590/1806-9649.2020v28e4769

\begin{abstract}
This article presents a bibliometric analysis on the Lean System over the period ranging from 2006 to 2017 , showing the evolution of the publications over the years, the number of publications per country, the main journals, the most prolific authors, the most used keywords, and eventually barriers for the implementation of the Lean System. The greatest growth of publication rate occurred from 2014 to 2015 . The countries with the most contribution have been the United Kingdom, the United States, and Sweden. The publications have been concentrated primarily in twelve journals. The bibliometric map of keywords presented them grouped into six clusters. Several underlying factors like technical and managerial aspects, planning, and leadership can explain the main barriers for the implementation of the Lean System. According to the literature, the understanding of such barriers is the best way to reduce the implementationtime and reach profitability and competitiveness. Therefore, the main contribution of this work is to make the evolution and importance of publications in this area are better known, helping organizations in the knowledge of the Lean System implementation barriers present in the literature, and in reformulating the curricula of undergraduate and postgraduate in disciplines related to Lean System. Finally, a future scientometric analysis on the subject is suggested, covering the analysis of evolution of publications, scientific journal, and authors distributions, by means of bibliometric laws, like those by Price, Bradford and Lotka, respectively.
\end{abstract}

Keywords: Barriers; Bibliometric methods; Lean system; Lean implementation; Barriers for Lean implementation.

Resumo: Este artigo apresenta uma análise bibliométrica sobre o Sistema Lean no período de 2006 a 2017, mostrando a evolução das publicações ao longo dos anos, o número de publicações por país, os principais periódicos, os autores mais prolíficos, as palavras-chave mais

Received Apr. 10, 2019 - Accepted Oct. 29, 2019

Financial support: This work has been supported by the Coordination for the Improvement of Higher Education Personnel - Brazil (CAPES) - Finance Code 001; and by the CNPq - Conselho Nacional de Desenvolvimento Científico e Tecnológico, grant number 304599/2015-8. 
usadas e, eventualmente, as barreiras para a implementação do Sistema Lean. O maior número de publicações ocorreu entre 2014 e 2015. Os países com maior contribuição foram o Reino Unido, os Estados Unidos e a Suécia. As publicações foram concentradas principalmente em doze periódicos. O mapa bibliométrico das palavras-chave apresentou um agrupamento em seis clusters. As principais barreiras encontradas podem ser explicadas por vários fatores subjacentes, relacionados à aspectos técnicos e gerenciais, de planejamento e liderança. De acordo com a literatura, o entendimento de tais barreiras é a melhor maneira de reduzir o tempo de implementação e alcançar lucratividade e competitividade. Portanto, a principal contribuição deste trabalho é fazer com que a evolução e importância das publicações nessa área sejam mais conhecidas, auxiliando as organizações no conhecimento das barreiras de implementação do Sistema Lean presentes na literatura, e auxiliar na reformulação dos currículos de graduação e pós-graduação em disciplinas relacionadas ao Sistema Lean. Por fim, sugere-se uma futura análise cientométrica sobre o assunto, abrangendo a análise da evolução das publicações, periódicos científicos e distribuições de autores, por meio de leis bibliométricas, como as de Price, Bradford e Lotka, respectivamente.

Palavras-chave: Barreiras; Métodos bibliométricos; Sistema Lean; Implementação do Lean; Barreiras para a implementação do Lean.

\section{Introduction}

After the World War Two, the Japanese automaker industry had the challenge to compete against his American peers that was eight times more productive. Therefore, the Japanese designed a new production system that, while based on Taylor and Ford's concepts (Murman et al., 2002) was mainly focused on eliminating all kinds of waste.

Such production system was first implemented at Toyota, so it was known as Toyota Production System (TPS). According to Womack et al. (1990) the TPS is renowned for its focus on reduction of the original Toyota seven wastes to improve overall customer value. The management philosophy of the TPS was firstly identified as lean by Krafcik (1988) and revealed to the world by Womack et al. (1990).

The implementation of the Lean System has been motivated by the expectation of positive results related to quality, safety, delivery improvements in addition to cost reduction (Moyano-Fuentes \& Sacristan-Diaz, 2012). The automotive industry pioneered the application of the Lean System, but today it is possible to see it running at many kinds of manufacturing industries such as electronics, steel, aerospace, machinery building and more.

In spite of all the benefits offered by the Lean System, during its implementation, several barriers emerge that discourage its application (Liker \& Rother, 2011).

Since Womack et al.'s (1990) publication, a lot of effort has been driven to understand and implement the Lean System, all over the world. Three decades of accumulated experience in the automotive industry have generated many examples of success and failure, which have been studied by several authors (Wincel \& Kull, 2013; Liker \& Rother, 2011; Bortolotti et al., 2015). Such studies have shown the existence of certain barriers that prevent the organizations from achieving better results. Such barriers can be classified as cultural, technological, etc (Bhasin, 2012; Netland, 2016; Mohammad \& Mohd, 2015).

Identifying these barriers is crucial to the success of the implementation of the Lean System as well as assuring the minimum implementation time to achieve the expected results (Simões, 2008). 
Bibliometric analysis investigates scientific publications through a series of procedures, such as publication outputs of different journals, countries, authors and citation analysis, and identifies pathways that centered more on content analysis and research evolution (Liu et al., 2011).

Based on that, this paper aims to investigate the performance of Lean System researches published from 2006 to 2017 in the Scopus database, to confirm the relevance of the theme, to find out the most relevant publications and its authors and the countries most interested in the subject by means of a bibliometric analysis. In addition, to identify the main barriers, found in selected articles, for the implementation of the Lean System.

This article is justified by the increase in the interest of scientific community in the use of bibliometric studies (Hu et al., 2014), and in the possibility contribution of reformulation of the curricula of the undergraduate and graduate courses in disciplines related to Lean System.

This bibliometric analysis is relevant to better understand the evolution of work on the Lean System in the academic community and to emphasize implementation barriers in the Lean System to assist organizations.

This paper is divided into four main sections: theoretical framework, which summarize the main concepts of the Lean System; methods, where the approach used by this research is presented; results and findings that presents and discuss the data extracted from the database and finally the conclusions that summarize the main points of the research.

\section{Theoretical framework}

Over the years, organizations around the world have implemented manufacturing philosophies (Anand \& Kodali, 2008), which focused on the elimination of waste in improving quality and reducing the time and cost of production (Ohno, 1997).

The Lean System can be considered a philosophy that assists in the identification and steady elimination of these wastes (Womack et al., 1990), with the main objective of reducing waste related to human effort, inventory, market time and manufacturing space, producing high quality products in an efficient and economical way that meet customer demand (Pavnaskar et al., 2003).

The main areas of focus within the Lean System objective are: flexibility, waste elimination, optimization, process control and people management (James-Moore \& Gibbons, 1997) and comprises tools used to structure, operate, control, manage and continuously improve various production systems (Detty \& Yingling, 2000) like Values Stream Mapping, Kanban, Total Productive Maintenance, Five S, Poka-Yoke, Control Charts, etc. These tools and others used in the Lean System can be classified in "Soft Lean" and "Hard Lean" (Bortolotti et al., 2015).

"Soft Lean" are related to social aspects human and relationship, like as employee training, problem solving and leadership engagement (Mamat et al., 2015) and "Hard Lean" refers to the technical and analytical tools of Lean System as Kanban, Just in Time and SMED. Although the "Hard Lean" tools are more used in the implementation of the Lean System, according to Bortolotti et al. (2015) the organizations that used the "Soft Lean" had better results, because they have a greater relation to the change of the organizational culture.

To reinforce the use of Soft practices in implementing the Lean System, Toyota proposed a new approach known as the Toyota Way. According to Liker (2004) this 
approach presents 4Ps, which are: Problem Solving, People \& Partnership, Process and Philosophy, known as Toyota's secrets to achieving the success of the Lean System, which will improve long term results.

The development of effective leadership is an important approach in the implementation of the Lean System, because the results are related to the commitment of the people, which is considered a Toyota approach (Liker, 2004; Osono et al., 2008).

It is important for organizations to invest in changes in leadership habits, behaviors and even mentality to ensure the success of the Lean System, because the link between the Lean System and a true organizational culture of continuous improvement is what has been lacking for many organizations to achieve the success (Mann, 2005). Some studies have concluded that increased performance and sustainable results in organizations have strong relationships between leadership, organizational culture and lean techniques (Wincel \& Kull, 2013; Krafcik, 1988; Katayama \& Bennett, 1996; Bartezzaghi, 1999).

Few organizations have achieved results like Toyota, even with the implementation of concepts, tools and approaches (Liker \& Rother, 2011). This was because of the barriers faced during the Lean implementation process. According to Mohammad \& Mohd (2015), these barriers may be technical, managerial, financial and even related to the attitudes of those involved. Identifying these barriers is an important step in achieving the best results of the Lean System.

\section{Methods}

The method employed for this research is illustrated in Figure 1.

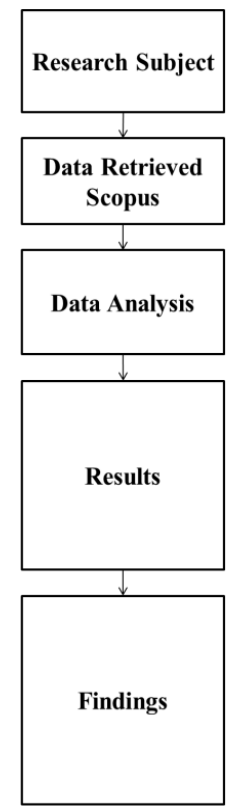

- Establish search term: barriers, lean implementation and critical success factor

- Choose platform (database): Scopus

- Parameters (search filters)

- Publication Type: articles

- Information: Title, authors, year of publication, number of citations, keywords and afiliations.

- Excel: visualization of the data : table and graphics

- VoSviewer: network cooperation

- Minitab: Principal Component Analysis

- Evolution of the publication - Score plot of the countries

- Number of publications per country - Scientific Journals

- Number of citations per publication - Most cited keywords

- Percentage of non-cited papers

- Number of citations of the most cited papers - Cited analysis

- Trend of publications and relevancy of the theme

- The countries that stand out most in publishing the theme

- Main journals and authors

- The clusters of the most used keywords

- The most cited articles

- Main barriers to a Lean System implementation

Figure 1. Research Methods. Source: Li et al. (2015). 


\subsection{Research subject}

Initially, the research was developed in the Scopus and Web of Science databases, but both databases have wide coverage of high impact journals and resemble many other aspects. Thus, the Scopus database was chosen, because "[...] it is the largest database of abstracts and citations in the literature with peer review: scientific journals, books, congresses processes and publications of the sector, presented intelligent tools to track, analyze and view researches" (Elsevier, 2018).

So, all information was collected in Scopus database, it was used the filter for document type as journal articles, excluding any other kind of documents. Also, it was only considered articles published from 2006 to 2017, using these dates as the time filter. For language filter it was considered English and Portuguese, to guarantee a greater number of articles. It was used the filter topic, that means that the papers were collected with the words located in titles, abstracts or keywords. For this filter it was first considered the words barriers and lean implementation that generated 72 results. It was decided to also include the words critical success factor (CSFs), as this antonym could also provide more information about Lean barriers. This new keyword's filter generated 111 more articles.

\subsection{Data retrieved}

The complete research contained 183 articles, although the words "lean implementation \& barriers" and "CSFs" were used as a topic filter for the database research, Scopus tool filter articles that do not discuss lean implementation, (some of them discuss about NOX emissions or Glycemic control, for example). Thus, the articles that present title and content related to the theme and the duplications of the publications were excluded from the research. Figure 2 shows all refinement from the data research.

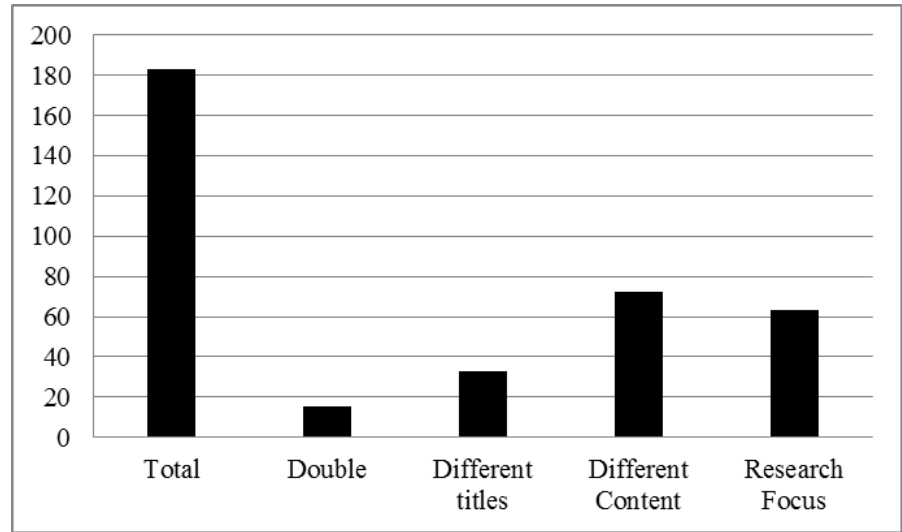

Figure 2. Lean implementation barriers/CSFs articles quantities details.

Among publications found in the research carried out in the database, 15 articles considered doubles was excluded. By reading the titles of publications, 33 publications did not present subjects related to the theme was discarded. Some papers present a different discuss from the theme, which led to the exclusion of other 72 publications.

Figure 3 shows the different contents presented in the excluded articles. 


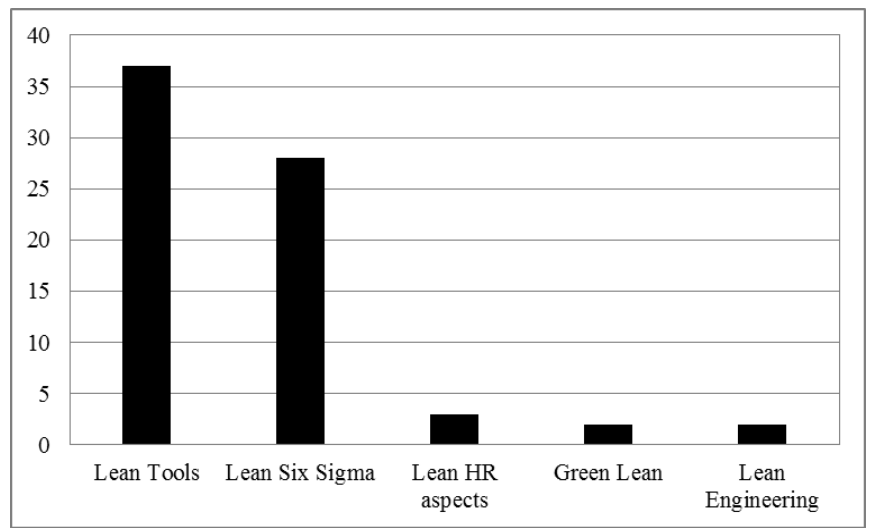

Figure 3. Number of specific lean approach's articles.

It can be seen in Figure 3, that these articles presented a lean specific approach's related to Lean Tools (37), Lean Six Sigma (28), Lean HR Aspects (3), Green Lean (2) and Lean Engineering (2), suggesting that these companies have implemented the Lean in different ways. After this evaluation, 63 articles were considered as the bibliographic portfolio, because it presented an alignment with the research theme.

\subsection{Data analysis}

The previous step retrieved a large amount of information that was summarized, for further analysis into tables and several types of graphs by means of software packages like Microsoft Excel, VoSviewer and Minitab.

\subsection{Results}

Several of the results obtained were the evolution of publications; the number of publications per country; the number of citations per publications; the percentage of non-cited papers; the number of citations of the most cited paper; the score plot of the countries; the scientific journals; the analysis of the most used keywords; the authors distribution; and the citation analysis.

\subsection{Findings}

Trend of publications and the relevancy of the theme; the countries that stand out most in publishing the theme; the main institutions and authors; the clusters of most used keywords; the most cited articles; and identifying main barriers to a Lean System implementation.

\section{Results and findings}

\subsection{Analysis of the evolution of publications}

As shown in Figure 2, after apply the search parameters, was selected 63 articles for bibliometrics analysis. Figure 4 shows the evolution of the publications, over the considered period of time. 


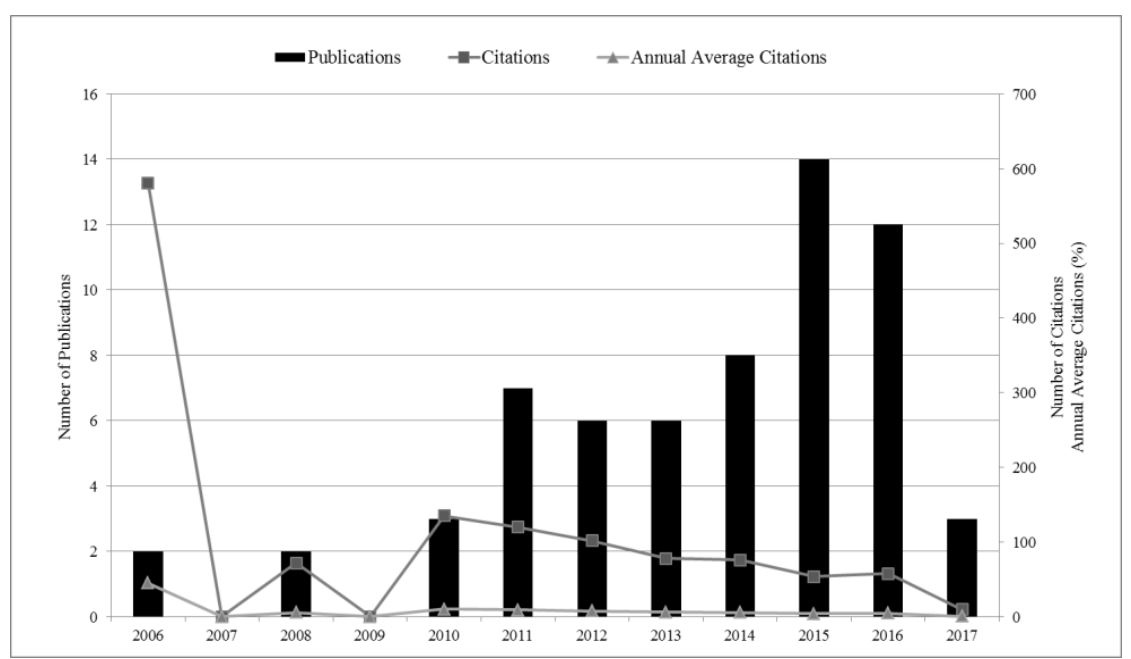

Figure 4. Evolution of the publication over the period 2006 to 2017 according to the Scopus database.

It can be seen from Figure 4 that between 2006 to 2010, the number of publications per year bounced between 0 and 3. Between 2011 and 2016, the number of publications increased at an average rate of approximately 8.84 publications per year. The greatest growth of publications rate occurred from 2014 to 2015.

The peak number of citations occurred in 2006 and 2010, and then decreased gradually during 2011-2017. In 2006, few articles were published, but well cited, which resulted in a higher percentage in the annual average of citations, in relation to the other years that presented the annual average of citations below $10 \%$.

Table 1 presents trends in the number of articles published from 2006 through 2017.

The number of authors per article increased significantly from 2011 to 2016. However, the average number of authors per article was higher in 2017, suggesting that over the years there was a greater interest in the theme by research groups. Overall, the average number of authors per article was quite stable.

Table 1. The characteristics of articles published between 2006 to 2017.

\begin{tabular}{cccccccc}
\hline Year & TP & AU & AU/TP & NR & NR/TP & PG & PG/TP \\
\hline 2006 & 2 & 6 & 3 & 138 & 69 & 27 & 13.5 \\
\hline 2007 & 0 & 0 & 0 & 0 & 0 & 0 & 0 \\
\hline 2008 & 2 & 3 & 1.5 & 49 & 24.5 & 20 & 10 \\
\hline 2009 & 0 & 0 & 0 & 0 & 0 & 0 & 0 \\
\hline 2010 & 3 & 7 & 2.3 & 118 & 39.3 & 28 & 9.3 \\
\hline 2011 & 7 & 18 & 2.5 & 237 & 33.8 & 78 & 11.2 \\
\hline 2012 & 6 & 15 & 2.5 & 203 & 33.8 & 68 & 11.3 \\
\hline 2013 & 6 & 18 & 3 & 423 & 70.5 & 107 & 17.8 \\
\hline 2014 & 8 & 23 & 2.8 & 481 & 60.1 & 114 & 14.2 \\
\hline 2015 & 14 & 41 & 2.9 & 675 & 48.2 & 212 & 15.1 \\
\hline 2016 & 12 & 31 & 2.6 & 727 & 60.6 & 216 & 18 \\
\hline 2017 & 3 & 11 & 3.6 & 276 & 92 & 64 & 21.3 \\
\hline
\end{tabular}

$T P$ : the number of total papers published per year; $A U$ : the number of authors; $N R$ : the number of cited references; PG: the number of pages; AU/TP, NR/TP and PG/TP: the average of authors, pages and references in a paper. 
The number of pages and references per paper had an increasing trend. The average number of references cited per paper changed dramatically after 2011. In addition, the average pages per article ranged between 9 and 21 .

It shows that this subject has been progressively explored, becoming a "hot knowledge area" for the researchers. It reinforces what was concluded by ScherrerRathje et al. (2009), that although Lean System was designed over more than 50 years ago, only in the last decade the organizations are considering its implementation as precondition to cost reduction and competitiveness. And its results are motivating other researchers from different sectors, such as services, publics and private, to explore the effects of the barriers in their LS implementation.

\subsection{Number of publications by country}

The descriptive bibliometrics results of the countries that published papers are seen in Table 2.

Table 2. Countries that published the articles.

\begin{tabular}{lccccc}
\hline \multicolumn{1}{c}{ COUNTRY } & PUBLICATIONS & CITATIONS & CPP & PNC & $\begin{array}{c}\text { MAX } \\
\text { CITES }\end{array}$ \\
\hline United States & 13 & 98 & 7.53 & 30.77 & 54 \\
\hline India & 8 & 72 & 9.00 & 25 & 30 \\
\hline Brazil & 7 & 17 & 2.43 & 42.86 & 5 \\
\hline United Kingdom & 7 & 639 & 91.29 & 0 & 283 \\
\hline Deutsche & 3 & 3 & 1.00 & 33.33 & 2 \\
\hline Malasya & 3 & 21 & 7.00 & 0 & 11 \\
\hline Belgium & 2 & 31 & 15.50 & 0 & 22 \\
\hline Denmark & 2 & 31 & 15.50 & 0 & 30 \\
\hline Italy & 2 & 4 & 2.00 & 0 & 2 \\
\hline Iran & 2 & 4 & 2.00 & 50.00 & 4 \\
\hline Netherland & 2 & 9 & 4.50 & 0 & 8 \\
\hline Sweden & 2 & 98 & 49.00 & 0 & 90 \\
\hline Nigeria & 1 & 0 & 0.00 & 100.00 & 0 \\
\hline China & 1 & 1 & 1.00 & 0 & 1 \\
\hline Czech Republic & 1 & 0 & 0.00 & 100.00 & 0 \\
\hline Dubai & 1 & 1 & 1.00 & 0 & 1 \\
\hline Lithuania & 1 & 2 & 2.00 & 0 & 2 \\
\hline New Zeland & 1 & 2 & 2.00 & 0 & 2 \\
\hline Norway & 1 & 4 & 4.00 & 0 & 4 \\
\hline Poland & 1 & 0 & 0.00 & 100.00 & 0 \\
\hline Spain & 1 & 6 & 6.00 & 0 & 6 \\
\hline Scotland & 1 & 0 & 0.00 & 100.00 & 0 \\
\hline CPP: cilaton & & & & & \\
\hline
\end{tabular}

CPP: citations per publication; PNC: percentage of non-cited papers; MAX CITES: the number of citations of the most cited article in the respective country.

Figure 5 shows the first six countries in number of publications. 


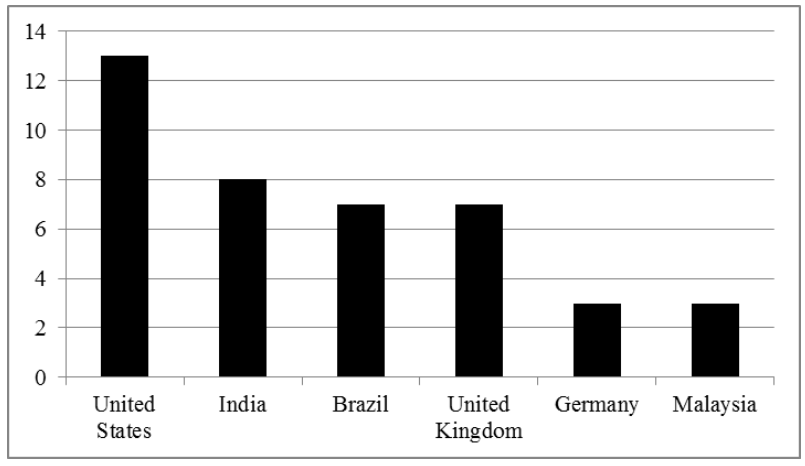

Figure 5. Number of publications per country.

It can be seen that United States (13), India (8), Brazil (7) and the United Kingdom (7) stand out. Germany (3) and Malaysia (3) shared the same position of the most productive countries.

The profile of citations is presented in Figure 6.

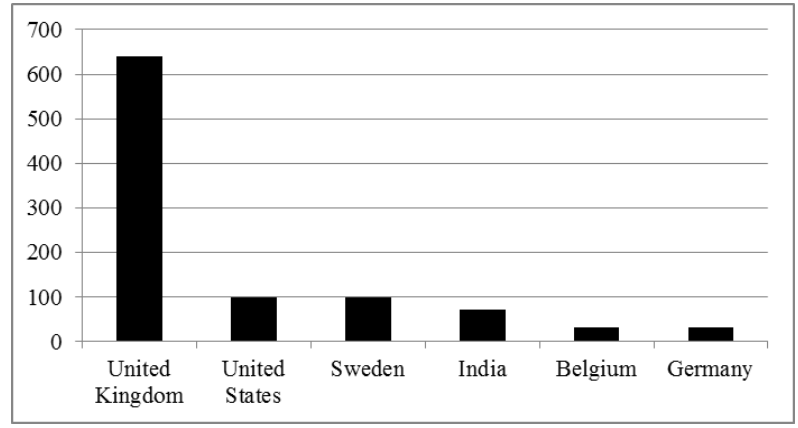

Figure 6. Number of citations per country.

In this figure, the first position is occupied by the United Kingdom (639) which presented a significant position compared to the other countries. United States (98) and Sweden (98) shared some position, followed by India (72), Belgium (31) and Germany (31).

The number of citations per publication (CPP) is presented in Figure 7.

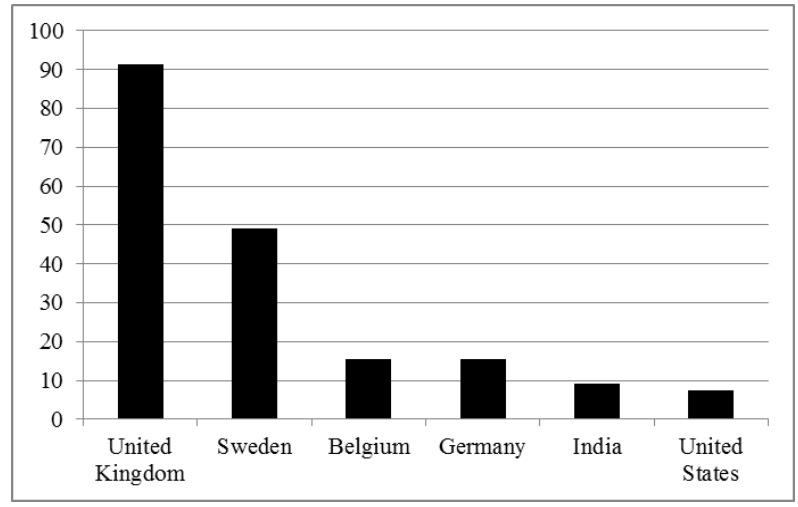

Figure 7. Number of citations per publication. 
Here, as in the previous chart, the first position is occupied by the United Kingdom (91.29). The only difference between this graphic and the shown presented in Figure 6 is the position the other countries, this occurred because some countries presented few publications, but relevant as to the number of citations, resulting an increasing in CPP, for example, Sweden (49.00) compared with the United States (7.53).

The percentage of publications non-cited (PNC) are illustrated in Figure 8.

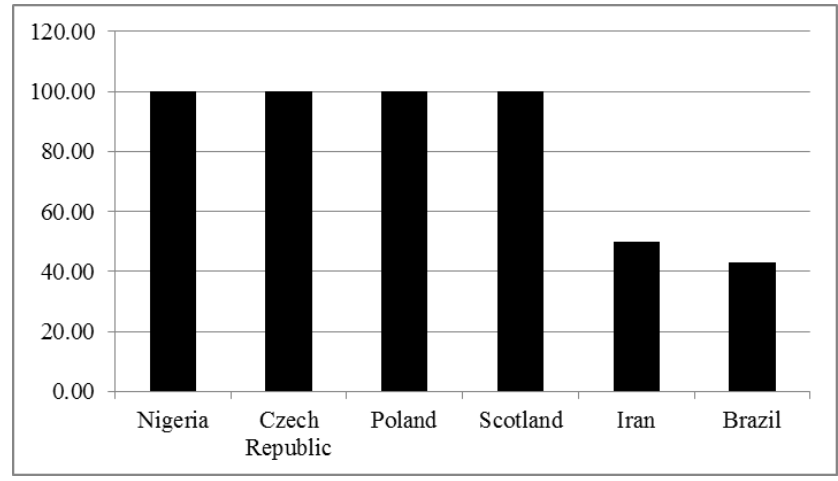

Figure 8. Percentage of publications non-cited.

The first position is occupied by Nigeria (100\%), Czech Republic (100\%), Poland $(100 \%)$ and Scotland (100\%), none publications in these countries have not been cited. Another point worth mentioned is the fact that although Brazil is in the third position in Figure 8 , more than fourth-two percent have not been cited. Iran (50\%) also has a large percentage of publications non-cited.

Figure 9 illustrates the number of citations of the most-cited article in each country for several countries.

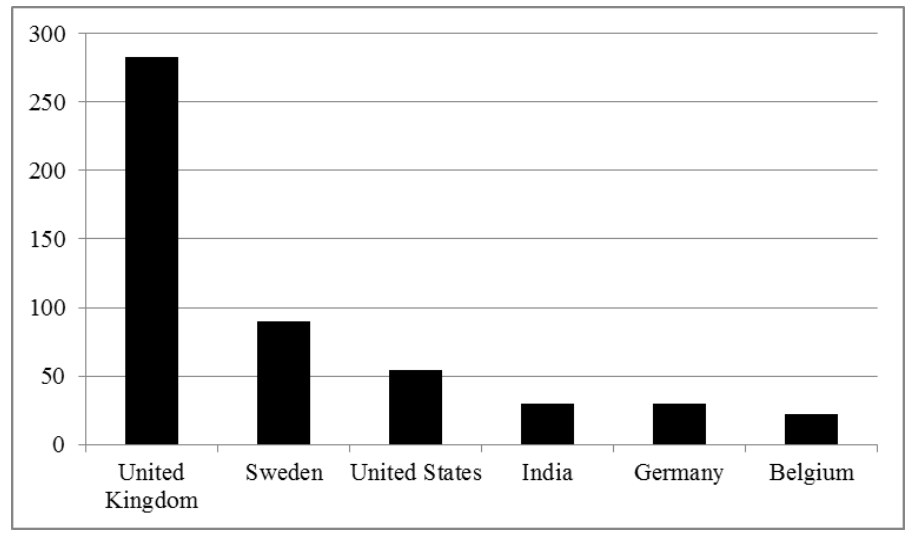

Figure 9. Number of citations of the most-cited article.

The graphic highlights the United Kingdom (283) position. Sweden (90) appears in the second position. United States (54) is ranked in the third place. The fourth position is occupied by India (30) and Germany (30). The most cited paper in the United Kingdom is far away from the most cited publication in any other country. 
The data from Table 2 have been submitted to a Principal Components Analysis (PCA) and Figure 10 shows the first and second components plotted against each other. Each data point represents a single country.

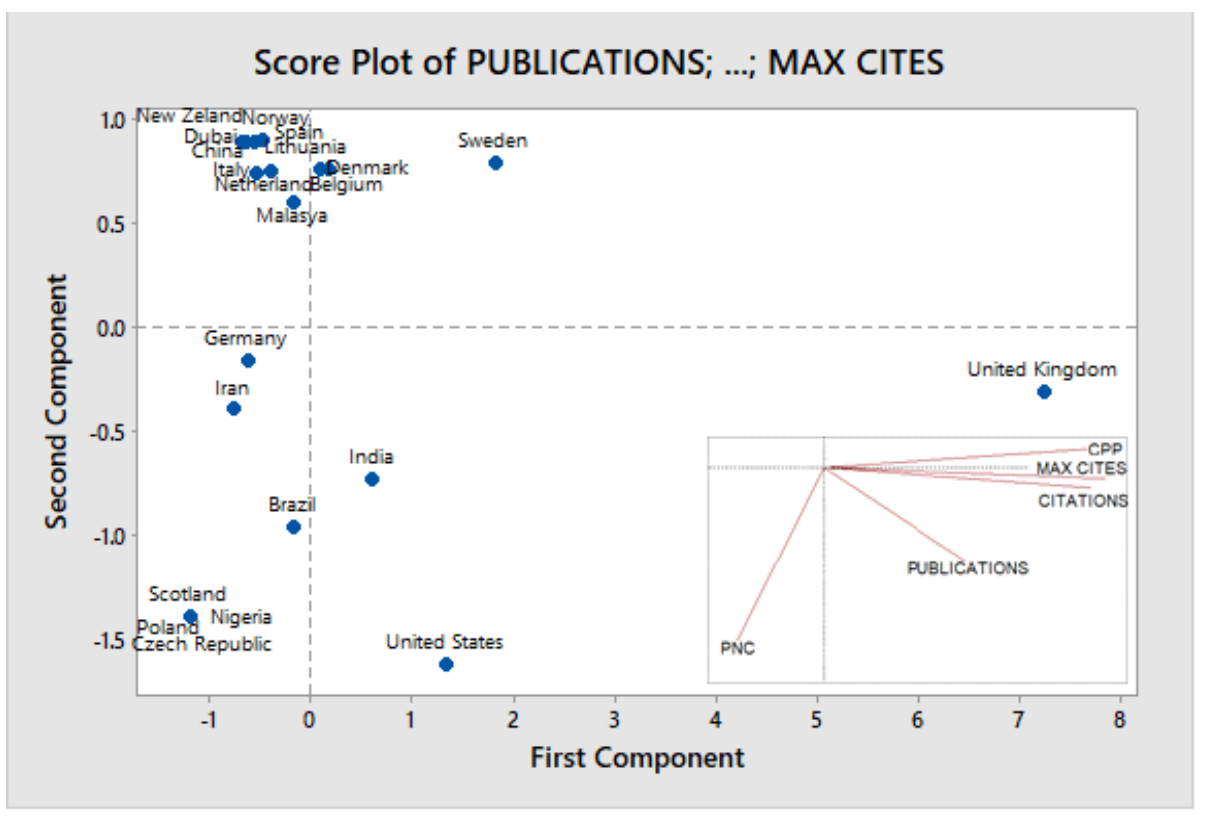

Figure 10. Principal component analysis.

The position of each country on the graph depicted in Figure 10 depends on a linear combination of all variables presented in Table 2. On the right upper of the graph can be seen the load plot for this analysis, which is useful in explaining the positioning of each country on the graph. The countries with higher citations, max cites and CPP are located on the upper right of the graph. As for the number of publications, the country is located at the bottom of the chart, with a trend to the right. As for the PNC, the countries are located at the bottom of the chart.

The United Kingdom stands out because of the number of citations, number of citations per publication and number of citations of the most cited paper. Scotland, Poland, Czech Republic and Nigeria stand out because of the percentage of publications non-cited. Although, the United States presented the highest number of publications, but also presented a high percentage of publications non-cited. The countries grouped together with China, Spain and Italy are in the upper left side of the chart because all their publications have been cited.

\subsection{Scientific journals}

The select 63 papers were published in 46 different journals, but most of these journals $(73.9 \%)$ only published one article. Table 3 presented the journals that published two or more articles related to the theme over the analysis period. The total of citations (TC) and the average number of citations per paper of a journal (TC/P) are also shown in Table 3, together with their respective SJR and $\mathrm{H}$-Index classification. 
Table 3. Relevant information about the main journals.

\begin{tabular}{|c|c|c|c|c|c|}
\hline Journal & Publications & TC & $\mathrm{TC} / \mathrm{P}$ & SJR & H-Index \\
\hline International Journal of Lean Six Sigma & 5 & 60 & 12 & 0.886 & 19 \\
\hline International Journal of Production Research & 3 & 23 & 7.6 & 1.463 & 101 \\
\hline $\begin{array}{l}\text { Inter. Journal of Prod. and Performance } \\
\text { Management }\end{array}$ & 3 & 56 & 18.6 & 0.607 & 36 \\
\hline British Food Journal & 2 & 33 & 16.5 & 0.466 & 46 \\
\hline Espacios & 2 & 0 & 0 & 0.170 & 3 \\
\hline International Journal for Quality Research & 2 & 14 & 7 & 0.234 & 7 \\
\hline $\begin{array}{l}\text { Journal of Manufacturing Technology } \\
\text { Management }\end{array}$ & 2 & 580 & 290 & 0.648 & 52 \\
\hline Mediterranean Journal of Social Sciences & 2 & 2 & 1 & 0.139 & 14 \\
\hline Production Planning and Control & 2 & 26 & 13 & 1.073 & 56 \\
\hline Quality Management in Health Care & 2 & 108 & 54 & 0.346 & 29 \\
\hline $\begin{array}{l}\text { Total Quality Management and Business } \\
\text { Excellence }\end{array}$ & 2 & 43 & 21.5 & 0.652 & 61 \\
\hline $\begin{array}{l}\text { Zeitschrift fuer Wirtschaftlichen Fabrikbetrieb } \\
\text { (ZWF) }\end{array}$ & 2 & 3 & 1.5 & 0.105 & 10 \\
\hline
\end{tabular}

TC: the total citations of a journal; TC/P: average number of overall citations per paper of a journal.

As can be seen in Table 3, the journal with the greatest number of publications is the International Journal of Lean Six Sigma (5) followed by the International Journal of Production Research (3), and the International Journal of Productivity and Performance Management (3). The Journal of Manufacturing Technology Management presented the highest TC score (580), followed by The Quality Management in Health Care (108). In addition, these journals also presented the highest TC/P score.

It is clear that The International Journal of Production Research, and The Production Planning and Control have higher SJR and H-index scores, demonstrating the competency of these journals.

\subsection{Analysis of the most used keywords}

The pattern of keywords that appear in articles of a gives of knowledge defines the underlying themes concerned with such a field. Therefore, when a set of publications is analyzed, the ideas, concepts, and methods that constitute this field of knowledge are defined by clusters of keyword that reflect commonality within a field of scientific research (Phillips et al., 2015).

According to Phillips et al. (2015) there are several strategies for visualizing textual data. This article uses bibliometric map for visualizing keywords associations, generated by VoSviewer software. Thus, it will be possible to study the formation of the clusters.

Figure 11 presents the map of keywords ranging from 2006 to 2017. 


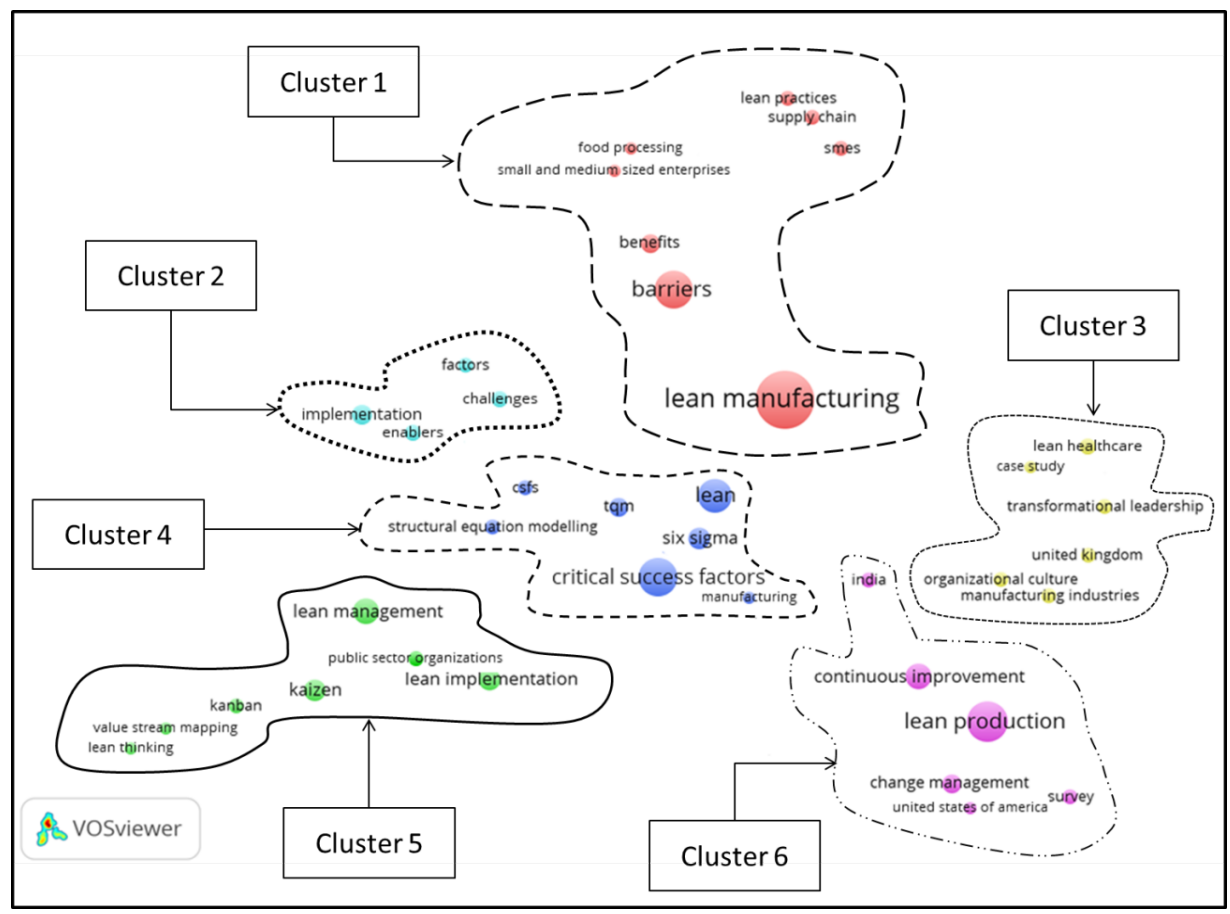

Figure 11. Map of keywords.

Over the period of analysis, 63 articles were selected, totalizing 188 keywords. The clustering algorithms use the frequency and strength of the connection of the keywords to create the clusters. Since many keywords were cited only once, many clusters containing only one element would arise obscuring the analysis (Cristino et al., 2018). Because of that, Figure 11 shows only the 38 keywords with frequency greater than or equal to 2, forming 6 clusters.

It can be seen in Figure 11, that the Cluster 1 presents articles related to the benefits and barriers to implementation of the Lean System. It seems that the researchers were delimited to small and medium sized enterprises and food processing. And some articles use SMEs as technique of Lean System. Cluster 2 groups terms related to the challenges of the implementation of the Lean System.

The main objective of the papers in Cluster 3 is the Lean System and organizational changes. It seems that the researches were delimited to manufacturing industries with a certain highlight to researches done in the United Kingdom. And the preferred methodological approach used by these researches was a case study.

Cluster 4 addresses the critical factors for implementing the Lean System and some of its tools. The keywords of Cluster 5 suggest articles interested in the Lean implementation process and some of its tools. These researches seem to be conducted mainly in public sector organizations.

The Lean Production and continuous improvement are the main objective of the articles grouped in Cluster 6 . The method employed by researches is survey. And the researches seem to be carried out in United States of America, and India. 


\subsection{Authors distribution}

In total, 157 authors have been acknowledged for making their contributions to this theme, only twelve authors have participated in more than one article. Table 4 shows the twelve most productive authors, including their respective number of publication, number of citations, $\mathrm{H}$-index, and country of origin.

Table 4. Authors' production.

\begin{tabular}{lcccl}
\hline \multicolumn{1}{c}{ Main Authors } & Publications & Citations & H-Index & Country \\
\hline Gellynck X. & 2 & 32 & 23 & Belgium \\
\hline Deros B.M. & 2 & 10 & 11 & Malaysia \\
\hline Rahman M.N.A. & 2 & 16 & 12 & Malaysia \\
\hline Kumar M. & 2 & 32 & 29 & India \\
\hline Dora M. & 2 & 32 & 5 & Belgium \\
\hline Tortorella G.L. & 2 & 5 & 5 & Brazil \\
\hline Marodin G.A. & 2 & 11 & 7 & United States \\
\hline Bhasin S. & 2 & 278 & 10 & Singapore \\
\hline Noori B. & 2 & 8 & 1 & Spain \\
\hline Costa L.B.M. & 2 & 6 & - & Brazil \\
\hline Shehab E. & 2 & 297 & 17 & United Kingdom \\
\hline Aij K.H. & 2 & 9 & 4 & Netherlands \\
\hline
\end{tabular}

The most productive authors published two articles on the subject. Shehab, E. (Cranfield University, Transport and Manufacturing, Cranfield, United Kingdom) is the most cited author, which that publications was cited 297 times. His most cited article (296) was "Critical success factors for lean implementation within SMEs" published in 2006.

The second most cited author is Bhasin, S. (NOMS College, Coventry, United Kingdom) which was cited 278 times. One of his publications exceeded 100 citations, namely: "Lean viewed as a philosophy" (243) published in 2006.

The third position of most cited authors was occupied for Gellynck, X. (Universiteit Gent, Department of Agricultural Economics, Ghent, Belgium), Kumar, M. (Cardiff University, Cardiff, United Kingdom) and Dora, M. (Brunel University London, Arts \& Social Sciences, Uxbridge, United Kingdom), that produced articles together. Their publications were cited 32 times and the most cited article was namely: "Application lean practice in small and medium-sized food enterprises" (22) published in 2014.

From $\mathrm{H}$-Index perspective, Kumar, $\mathrm{M}$. has a higher score, which reflects on his influence in this research area. The other authors that also has a higher $\mathrm{H}$-Index are Gellynck X., and Shehab E.

\subsection{Citation analysis}

The ten most cited publications are shown in Appendix 1, including number of citations, the article's title, the authors, the journal to which it belongs, volume and edition, pages, the year of publication of the article and evolution of the quotations from the year 2006 until 2017. 
The most cited article, "Critical success factors for lean implementation within SMEs", by Achanga et al. (2006), which proposes to outline some of the factors that are perceived to be critical in the successful application of lean manufacturing within SMEs community. According, the number of citations per year, this article presents the greatest number of citations in 2016.

The second most cited article is "Lean viewed as a philosophy", by Bhasin \& Burcher (2006), that started to be cited in 2008 , and presented the highest number of citations in 2015.

The article "The current state of Lean implementation oh health care: literature review", by Poksinska (2010), is the third most cited paper, which began to be cited in 2012 and presented a higher peak of citation in 2016.

The fourth most cited article is "Implementing Lean production systems: barriers to change", by Sim \& Rogers (2008), cited 54 times since 2011 and the highest number of citations occurred in 2015.

The authors Souza \& Pidd (2011) published the article "Exploring the barriers to Lean healthcare implementation" in 2011, which present the greatest number of citations in 2014.

It is possible to observe that the ten most cited articles began to be cited one year after the year of publication, and the annual peak of citations of these articles happened from 2014.

The analysis of publications topic showed that there was also a growth of publications after 2014, suggesting that articles previously developed were more cited in the period when there was a greater number of published papers.

\subsection{Main barriers}

The bibliographic research indicates different barriers to a Lean System implementation and the same barriers had different denominations by the authors. For example, Bhasin (2012) cited in their research, the lack of top management support as a barrier, and Netland (2016) named the same barrier like the lack of high management commitment and involvement.

In order to have a standard designation for all barriers found in the articles, a content analysis was done. The results generated 14 main barriers that are presented in Table 5.

It is important to note that the barriers are related to human, managerial, planning and cultural aspects which reinforces the arguments of Bhasin \& Burcher (2006) that the Lean System is a philosophy not only a set of techniques.

The barriers related to the planning aspects of the Lean System are: Project selection/ Priorization difficulties, Implementation team failures, Implementation plan failures, Lack of financial resources, Layouts/ Product/ Process Difficulties and Interdepartmental conflicts. 
Table 5. Content analysis for portfolio Lean Implementation barriers.

\begin{tabular}{|c|c|c|c|c|}
\hline $\begin{array}{l}\frac{士}{d} \\
\frac{0}{0} \\
\frac{0}{4}\end{array}$ & Barriers & Features & Authors & $F$ \\
\hline \multirow{14}{*}{ 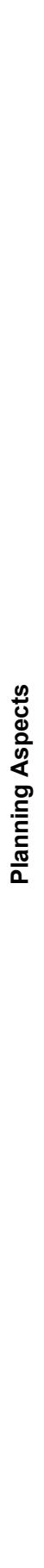 } & \multirow{3}{*}{$\begin{array}{l}\text { Project Selection/ } \\
\text { Priorization } \\
\text { difficulties }\end{array}$} & $\begin{array}{l}\text { - No criteria to prioritize the } \\
\text { projects }\end{array}$ & $\begin{array}{l}\text { Sahwan et al. (2012); } \\
\text { Mahmutaj et al. (2015); Jasti } \\
\text { \& Kodali (2016). }\end{array}$ & \multirow{3}{*}{16} \\
\hline & & $\begin{array}{l}\text { - Lots of projects occurring at } \\
\text { the same time, competing } \\
\text { Lean System team attention }\end{array}$ & $\begin{array}{c}\text { Gupta et al. (2013); Bhasin \& } \\
\text { Burcher (2006); Leme et al. } \\
\text { (2016); Murugesan et al. } \\
\text { (2012). }\end{array}$ & \\
\hline & & $\begin{array}{l}\text { - Difficulties to conciliate goals } \\
\text { for all projects, sometimes } \\
\text { compromising medium term } \\
\text { goals instead of short term } \\
\text { one }\end{array}$ & $\begin{array}{l}\text { Marodin \& Saurin (2015); } \\
\text { Worley \& Doolen (2015); } \\
\text { Mahmutaj et al. (2015). }\end{array}$ & \\
\hline & \multirow{3}{*}{$\begin{array}{l}\text { Implementation } \\
\text { team failures }\end{array}$} & - Inadequate team selection & $\begin{array}{c}\text { Dora et al. (2013); } \\
\text { Jadhav et al. (2014); } \\
\text { Sahwan et al. (2012); Bhasin } \\
\text { (2012); Pedersen \& Huniche } \\
\text { (2011). }\end{array}$ & \multirow{3}{*}{19} \\
\hline & & - Lack of Lean knowledge & $\begin{array}{l}\text { Jasti \& Kodali (2016); } \\
\text { Marodin \& Saurin (2015); } \\
\text { Dora et al. (2013); } \\
\text { Sahwan et al. (2012); } \\
\text { Poksinska (2010). }\end{array}$ & \\
\hline & & $\begin{array}{l}\text { - Lack of project planning or } \\
\text { implementation conduction }\end{array}$ & $\begin{array}{l}\text { Dora et al. (2013); } \\
\text { Mahmutaj et al. (2015); } \\
\text { Näslund (2013); Kundu \& } \\
\text { Murali Manohar (2012). }\end{array}$ & \\
\hline & \multirow{3}{*}{$\begin{array}{l}\text { Implementation } \\
\text { plan failures }\end{array}$} & $\begin{array}{l}\text { • Difficulties on } \\
\text { implementation follow-up }\end{array}$ & $\begin{array}{l}\text { Leme et al. (2016); Noori } \\
\text { (2015); Ihueze and Okpala } \\
\text { (2011). }\end{array}$ & \multirow{3}{*}{27} \\
\hline & & $\begin{array}{l}\text { - Project action dates are } \\
\text { usually being postponed }\end{array}$ & $\begin{array}{l}\text { Neumann et al. (2015); } \\
\text { Leme et al. (2016). }\end{array}$ & \\
\hline & & $\begin{array}{l}\text { - Difficulties on measuring } \\
\text { financial results }\end{array}$ & $\begin{array}{c}\text { Marodin \& Saurin (2015); } \\
\text { Carmignani \& Zammori (2015); } \\
\text { Rees (2014). }\end{array}$ & \\
\hline & $\begin{array}{l}\text { Lack of financial } \\
\text { resources }\end{array}$ & $\begin{array}{l}\text { - Lack of financial resources } \\
\text { for layouts redesign and } \\
\text { devices or machines } \\
\text { acquirements }\end{array}$ & $\begin{array}{c}\text { Jasti \& Kodali (2016); } \\
\text { Dora et al. (2013); Marodin \& } \\
\text { Saurin (2015); Jadhav et al. } \\
\text { (2014); Al-Najem et al. } \\
\text { (2013). }\end{array}$ & 6 \\
\hline & \multirow{2}{*}{$\begin{array}{l}\text { Layouts/ Product/ } \\
\text { Process difficulties }\end{array}$} & $\begin{array}{c}\text { - New system adaptation is } \\
\text { not so clear to a specific } \\
\text { product, layout or even } \\
\text { process }\end{array}$ & $\begin{array}{l}\text { Bhasin \& Burcher (2006); } \\
\text { Rose et al. (2014). }\end{array}$ & \multirow{2}{*}{13} \\
\hline & & $\begin{array}{l}\text { - Obstacles on new customer } \\
\text { / supplier interfaces }\end{array}$ & $\begin{array}{l}\text { Jasti \& Kodali (2016); } \\
\text { Jadhav et al. (2014); } \\
\text { Sahwan et al. (2012); } \\
\text { Mahmutaj et al. (2015). }\end{array}$ & \\
\hline & \multirow{2}{*}{$\begin{array}{l}\text { Interdepartmental } \\
\text { conflicts }\end{array}$} & $\begin{array}{l}\text { - Different goals for each } \\
\text { department }\end{array}$ & $\begin{array}{l}\text { Achanga et al. (2006); } \\
\text { Dammand et al. (2014). }\end{array}$ & \multirow[b]{2}{*}{8} \\
\hline & & $\begin{array}{l}\text { - Support areas are not } \\
\text { responsible for their actions in } \\
\text { the project }\end{array}$ & $\begin{array}{l}\text { Elnadi \& Shehab (2015), } \\
\text { Hwang et al. (2014). }\end{array}$ & \\
\hline
\end{tabular}


Table 5. Continued..

\begin{tabular}{|c|c|c|c|c|}
\hline 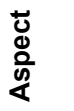 & Barriers & Features & Authors & $F$ \\
\hline \multirow{4}{*}{ 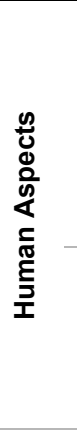 } & \multirow[t]{2}{*}{$\begin{array}{l}\text { Lack of employee } \\
\text { involvement in } \\
\text { project decision }\end{array}$} & $\begin{array}{l}\text { - Employees are not involved } \\
\text { during the project causing } \\
\text { reworks and difficulties of } \\
\text { implementation }\end{array}$ & $\begin{array}{c}\text { Costa et al. (2017); } \\
\text { Jadhav et al. (2014); Al- } \\
\text { Najem et al. (2013); Rossiter } \\
\text { Hofer et al. (2011); } \\
\text { Abuhejleh et al. (2016). }\end{array}$ & \multirow[t]{2}{*}{11} \\
\hline & & $\begin{array}{l}\text { - Employees' mindset is not } \\
\text { impacted by the project }\end{array}$ & $\begin{array}{l}\text { Rane et al. (2016); Marodin } \\
\text { and Saurin (2015). }\end{array}$ & \\
\hline & \multirow{2}{*}{$\begin{array}{l}\text { Employee } \\
\text { insecurity }\end{array}$} & $\begin{array}{l}\text { - Employees are afraid to be } \\
\text { fired after the implementation }\end{array}$ & $\begin{array}{l}\text { Costa et al. (2017); Jasti \& } \\
\text { Kodali (2016); Elnadi \& } \\
\text { Shehab (2015). }\end{array}$ & \multirow[t]{2}{*}{9} \\
\hline & & $\begin{array}{l}\text { - Employees are not confident } \\
\text { in execute their new roles }\end{array}$ & $\begin{array}{l}\text { Costa et al. (2017); Bhasin } \\
\text { (2012); Hung et al. (2015). }\end{array}$ & \\
\hline \multirow{11}{*}{ 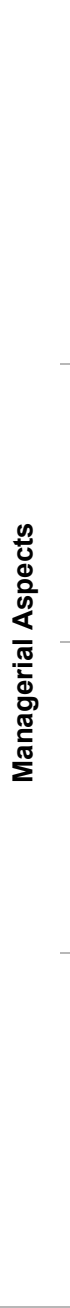 } & \multirow{4}{*}{$\begin{array}{l}\text { Lack of top } \\
\text { management } \\
\text { support }\end{array}$} & $\begin{array}{l}\text { - Implementation efforts not } \\
\text { recognized by leadership }\end{array}$ & $\begin{array}{l}\text { Schuh et al (2012); Bhasin } \\
\text { (2012). }\end{array}$ & \multirow{4}{*}{22} \\
\hline & & $\begin{array}{l}\text { - Lack of leadership guidance } \\
\text { during the process }\end{array}$ & $\begin{array}{l}\text { Rane et al. (2016); Djassemi } \\
\text { (2014). }\end{array}$ & \\
\hline & & $\begin{array}{c}\text { - Lack of alignment between } \\
\text { the improvement project and } \\
\text { business goals }\end{array}$ & $\begin{array}{l}\text { Zhou (2016); Djassemi } \\
\text { (2014). }\end{array}$ & \\
\hline & & $\begin{array}{l}\text { - Leadership does not help } \\
\text { overcome difficulties during } \\
\text { the implementation process }\end{array}$ & $\begin{array}{l}\text { Costa et al. (2017); } \\
\text { Manzouri et al. (2013). }\end{array}$ & \\
\hline & \multirow{2}{*}{$\begin{array}{l}\text { Communication } \\
\text { obstacles }\end{array}$} & $\begin{array}{l}\text { - Lack of communication in } \\
\text { the organization about the } \\
\text { status of the Lean system } \\
\text { implementation project }\end{array}$ & $\begin{array}{l}\text { Jasti \& Kodali (2016); } \\
\text { Čiarnienè \& Vienažindienè } \\
\text { (2014). }\end{array}$ & \multirow{2}{*}{7} \\
\hline & & $\begin{array}{l}\text { - Difficulties to guarantee } \\
\text { communication between } \\
\text { shifts, departments or } \\
\text { organizational levels }\end{array}$ & $\begin{array}{l}\text { Costa et al. (2017); Zhou } \\
\text { (2016); Rees (2014). }\end{array}$ & \\
\hline & \multirow[b]{2}{*}{ Lack of training } & $\begin{array}{c}\text { - Employees do not receive } \\
\text { enough training about Lean } \\
\text { techniques }\end{array}$ & $\begin{array}{c}\text { Costa et al. (2017); Hung et al } \\
\text { (2015); Jadhav et al. (2014); } \\
\text { Dora et al. (2013); Aij et al. } \\
\text { (2013). }\end{array}$ & \multirow[b]{2}{*}{25} \\
\hline & & $\begin{array}{l}\text { - Employees were not trained } \\
\text { for their new roles }\end{array}$ & $\begin{array}{c}\text { Costa et al. (2017); } \\
\text { Hung et al. (2015); } \\
\text { Jadhav et al. (2014); } \\
\text { Dora et al. (2013); Aij et al. } \\
\text { (2013); Poksinska (2010). }\end{array}$ & \\
\hline & \multirow{3}{*}{$\begin{array}{l}\text { Medium } \\
\text { management } \\
\text { reluctance }\end{array}$} & $\begin{array}{l}\text { - Managers do not support } \\
\text { implementation }\end{array}$ & $\begin{array}{c}\text { Marodin \& Saurin (2015); } \\
\text { Jadhav et al. (2014); Aij et al. } \\
\text { (2013); Pedersen \& Huniche } \\
\text { (2011). }\end{array}$ & \multirow{3}{*}{16} \\
\hline & & $\begin{array}{l}\cdot \text { Lack of commitment of } \\
\text { management to the project }\end{array}$ & $\begin{array}{c}\text { Dora et al. (2013); } \\
\text { Jadhav et al. (2014); Aij et al } \\
\text { (2013); Al-Najem et al. } \\
(2013) .\end{array}$ & \\
\hline & & $\begin{array}{l}\text { - Managers do not believe in } \\
\text { project results }\end{array}$ & $\begin{array}{c}\text { Jasti \& Kodali (2016); Rossiter } \\
\text { Hofer et al. (2011) }\end{array}$ & \\
\hline \multirow{2}{*}{ 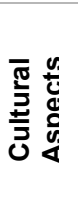 } & \multirow{2}{*}{$\begin{array}{l}\text { Implementation } \\
\text { sustainable } \\
\text { problems }\end{array}$} & $\begin{array}{l}\text { - At first obstacles, employees } \\
\text { return to old practices or } \\
\text { culture; }\end{array}$ & $\begin{array}{l}\text { Marodin \& Saurin (2015); } \\
\text { Bhasin (2012); } \\
\text { Neumann et al. (2015); } \\
\text { McLean et al. (2017). }\end{array}$ & \multirow[t]{2}{*}{13} \\
\hline & & $\begin{array}{l}\text { - No follow-up to guarantee } \\
\text { new practices }\end{array}$ & $\begin{array}{l}\text { Costa et al. (2017); } \\
\text { Manzouri et al. (2013). }\end{array}$ & \\
\hline
\end{tabular}




\begin{tabular}{|c|c|c|c|c|}
\hline $\begin{array}{l}\text { பू } \\
\frac{0}{0} \\
\frac{0}{4}\end{array}$ & Barriers & Features & Authors & $\boldsymbol{F}$ \\
\hline & & $\begin{array}{l}\text { - New practices are only } \\
\text { performed with the eyes of the } \\
\text { Lean team/management, after } \\
\text { that everything returns to the } \\
\text { old ones. }\end{array}$ & $\begin{array}{c}\text { Vinodh \& Joy (2012); } \\
\text { Achanga et al. (2006); } \\
\text { Nahmens \& Mullens (2011). }\end{array}$ & \\
\hline & Cultural differences & $\begin{array}{l}\text { - Difficulties to adapt elements } \\
\text { from Lean System as } \\
\text { discipline, long term vision } \\
\text { and others to a different } \\
\text { organizational culture. }\end{array}$ & $\begin{array}{c}\text { Jadhav et al. (2014); } \\
\text { Sahwan et al. (2012); Bhasin } \\
\text { (2012); Pedersen \& Huniche } \\
\text { (2011); Sisson \& Elshennawy } \\
\text { (2015). }\end{array}$ & 8 \\
\hline
\end{tabular}

Those related to the managerial aspects are Lack of top management support, Communication obstacles, Lack of training and Medium management reluctance.

The barriers concerned with the human aspects are Lack of employee involvement in project decisions and Employee insecurity.

Implementation Sustainable Problems and Cultural Differences are concerned with cultural aspects.

\section{Conclusion}

This paper describes a bibliometrics analysis concerned with the barriers faced by the organizations while implementing the Lean System. This article investigated the evolution of publications on the theme from 2006 to 2017.

The greatest growth of publications rate occurred from 2015 to 2016 . The peak number of citations occurred in 2006 and 2010, and the decreased gradually during 2011-2017. The growth was drive by Europe after 2009, by Asia after 2010, and by North America after 2013.

The United States are the country with the greatest number of publications (13) followed by India (8) and Brazil (7) and The United Kingdom (7).

The most cited countries are the United Kingdom (639), the United States (98), Sweden (98) and India (72). It is remarkable the difference between the United Kingdom and the others. Recall that the total publications assigned to the United Kingdom are only 7 articles, this leads to the conclusion that the quality of the United Kingdom's publications is high and, perhaps, the authors from the United Kingdom are renown as authorities on this subject. This conclusion can be reinforced by the fact that the most cited paper (283) was published in the United Kingdom. It is worth mentioning that Sweden has only two publications and one of them was cited 90 times, therefore it can be concluded that such a paper can be considered very relevant.

Several countries such as Nigeria, Czech Republic and Poland did not received any citation. Interesting to note, however, is that Germany, which usually has great investments in research, published only three papers in this area and just one of them has been cited.

The most relevant areas related to the theme were Operations, Management, Healthcare, and Engineering.

Operations area contained publications dealing with different industrial branches. Management area grouped articles that address the subject applied in the industrial sectors. Healthcare area presented papers that were correlated with the 
implementation of Lean System in hospital. Engineering area contained papers that approach the theme related to the automotive industries.

The 63 articles were distributed among 46 journals, but most of these journals only published one article. The International Journal of Lean Six Sigma was the scientific journal that had published more of the paper related to the theme. The journals with a highest SJR and H-Index score was International Journal of Production Research, and Production Planning and Control, which demonstrated the competency of these journals.

A bibliometric map of keywords covering the period of analysis (2006-2017), have been employed. Thus, it was possible to study a formation of the clusters, to understand the key topics in this field of knowledge. During this period, the bibliometric map showed 188 keywords, but only 38 keywords occurred two or more times, forming 6 clusters.

The total of authors involved in the production of these 63 articles was 157 . The most productive authors published two articles each. The most cited authors was Shehab, E. (Cranfield University, Transport and Manufacturing, Cranfield, United Kingdom), whose publications was cited 297 times and Bhasin, S. (NOMS College, Coventry, United Kingdom) that was cited 278 times.

This research pointed out the 14 main barriers to implementation of the Lean System faced by the management staff of several companies from diverse segments of the economy. This barriers included several aspects such as technical, managerial, planning and leadership, and are the main obstacles for reducing the implementation time. The literature claims that the comprehension of such barriers is the best way to overcome them and reach profitability and competitiveness.

The main contribution of this work was to make the evolution and importance of publications in this area are better known, helping organizations in the knowledge of the Lean System implementation barriers present in the literature, and in reformulating the curricula of undergraduate and postgraduate in disciplines related to Lean System.

The limitation found in the research was that some aspects deserve more detailed investigations, which may provide subsidies for a more complete analysis of the literature behavior of this specific area. Therefore, a future scientometric analysis on the subject is suggested, covering the analysis of evolution of publications, scientific journal, and authors distributions, by means of bibliometric laws, like those by Price, Bradford, and Lotka, respectively.

\section{References}

Abuhejleh, A., Dulaimi, M., \& Ellahham, S. (2016). Using lean management to leverage innovation in healthcare projects: case study of a public hospital in the UAE. BMJ Innovations, 2(1), 22-32. http://dx.doi.org/10.1136/bmjinnov-2015-000076.

Achanga, P., Shehab, E., Roy, R., \& Nelder, G. (2006). Critical success factors for lean implementation within SMEs. Journal of Manufacturing Technology Management, 17(4), 460-471. http://dx.doi.org/10.1108/17410380610662889.

Aij, K. H., Simons, F. E., Widdershoven, G. A. M., \& Visse, M. (2013). Experiences of leaders in the implementation of Lean in a teaching hospital: barriers and facilitators in clinical practices: a qualitative study. BMJ Open, 3(10), e003605. http://dx.doi.org/10.1136/bmjopen-2013-003605. PMid:24171938.

Al-Najem, M., Dhakal, H., Labib, A., \& Bennett, N. (2013). Lean readiness level within Kuwaiti manufacturing industries. International Journal of Lean Six Sigma, 4(3), 280-320. http://dx.doi.org/10.1108/IJLSS-05-2013-0027. 
Anand, G., \& Kodali, R. (2008). Selection of lean manufacturing systems using the PROMETHEE. Journal of Modelling in Management, 3(1), 40-70.

http://dx.doi.org/10.1108/17465660810860372.

Bartezzaghi, E. (1999). The evolution of production models: is a new paradigm emerging? International Journal of Operations \& Production Management, 19(2), 229-250. http://dx.doi.org/10.1108/01443579910247446.

Bhasin, S. (2012). Prominent obstacles to lean. International Journal of Productivity and Performance Management, 61(4), 403-425. http://dx.doi.org/10.1108/17410401211212661.

Bhasin, S., \& Burcher, P. (2006). Lean viewed as a philosophy. Journal of Manufacturing Technology Management, 17(1), 56-72. http://dx.doi.org/10.1108/17410380610639506.

Bortolotti, T., Boscari, S., \& Danese, P. (2015). Successful lean implementation: organizational culture and soft lean practices. International Journal of Production Economics, 160, 182201. http://dx.doi.org/10.1016/j.ijpe.2014.10.013.

Carmignani, G., \& Zammori, F. (2015). Lean thinking in the luxury-fashion market. International Journal of Retail \& Distribution Management, 43(10-11), 988-1012. http://dx.doi.org/10.1108/IJRDM-07-2014-0093.

Čiarnienè, R., \& Vienažindienè, M. (2014). How to facilitate implementation of lean concept? Mediterranean Journal of Social Sciences, 5(13), 177-183. Retrieved in 2018, July 29, from hub.tw/10.5901/mjss.2014.v5n13p177

Costa, L. B. M., Godinho, M., Fo., Rentes, A. F., Bertani, T. M., \& Mardegan, R. (2017). Lean healthcare in developing countries: evidence from Brazilian hospitals. The International Journal of Health Planning and Management, 32(1), e99-e120. http://dx.doi.org/10.1002/hpm.2331. PMid:26681656.

Cristino, T. M., Faria, A., No., \& Costa, A. F. B. (2018). Energy efficiency in buildings: analysis of scientific literature and identification of data analysis techniques from a bibliometric study. Scientometrics, 114(3), 1275-1326. http://dx.doi.org/10.1007/s11192-017-2615-4.

Dammand, J., Hørlyck, M., Jacobsen, T. L., Lueg, R., \& Röck, R. L. (2014). Lean management in hospitals: evidence from Denmark. Administratie si Management Public, (23), 19-35. Retrieved in 2018, July 29, from http://www.ramp.ase.ro/en/_data/files/articole/2014/2302.pdf

Detty, R. B., \& Yingling, J. C. (2000). Quantifying benefits of conversion to lean manufacturing with discrete event simulation: a case study. International Journal of Production Research, 38(2), 429-445. http://dx.doi.org/10.1080/002075400189509.

Djassemi, M. (2014). Lean adoption in small manufacturing shops: attributes and challenges. Journal of Technology, Management, and Applied Engineering, 30(1), 2-10. Retrieved in 2018, July 29, from

https://cdn.ymaws.com/www.atmae.org/resource/resmgr/articles/djassemi-lean-smallmanufact.pdf

Dora, M., Van Goubergen, D., Kumar, M., Molnar, A., \& Gellynck, X. (2013). Application of lean practices in small and medium-sized food enterprises. British Food Journal, 116(1), 125141. http://dx.doi.org/10.1108/BFJ-05-2012-0107.

Elnadi, M., \& Shehab, E. (2015). Main enablers and factors for successful implementation of lean in product-service systems. International Journal of Agile Systems and Management, 8(3-4), 332-354. http://dx.doi.org/10.1504/IJASM.2015.073542.

Elsevier. (2018). Scopus: an eye on global research: 5,000 publishers. Over $71 \mathrm{M}$ records and 23,700 titles. Retrieved in 2018, July 29 , from https://www.elsevier.com/_data/assets/pdf_file/0008/208772/ACAD_R_SC_FS.pdf

Gupta, V., Acharya, P., \& Patwardhan, M. (2013). A strategic and operational approach to assess the lean performance in radial tyre manufacturing in India: a case based study. International Journal of Productivity and Performance Management, 62(6), 634-651. http://dx.doi.org/10.1108/IJPPM-Jun-2012-0057. 
Hu, Y., Sun, J., Li, W., \& Pan, Y. (2014). A scientometric study of global electric vehicle research. Scientometrics, 98(2), 1269-1282. http://dx.doi.org/10.1007/s11192-013-1067-8.

Hung, D., Martinez, M., Yakir, M., \& Gray, C. (2015). Implementing a lean management system in primary care: facilitators and barriers from the front lines. Quality Management in Health Care, 24(3), 103-108. http://dx.doi.org/10.1097/QMH.0000000000000062. PMid:26115057.

Hwang, P., Hwang, D., \& Hong, P. (2014). Lean practices for quality results: a case illustration. International Journal of Health Care Quality Assurance, 27(8), 729-741. http://dx.doi.org/10.1108/IJHCQA-03-2014-0024. PMid:25417378.

Ihueze, C. C., \& Okpala, C. C. (2011). A survey of Optimum Manufacturing Strategy as a tool for enhanced industrial revenue. Australian Journal of Basic and Applied Sciences, 5(12), 1321-1329. Retrieved in 2018, July 29, from https://www.researchgate.net/profile/Christopher_ Chukwutoo_Ihueze/publication/266411030_A_Survey_of_Optimum_Manufacturing_Strate gy_as_a_Tool_for_Enhanced_Industrial_Revenue/links/5528b9060cf2779ab78e1716/ASurvey-of-Optimum-Manufacturing-Strategy-as-a-Tool-for-Enhanced-IndustrialRevenue.pdf

Jadhav, R. J., Mantha, S. S., \& Rane, B. S. (2014). Exploring barriers in lean implementation. International Journal of Lean Six Sigma, 5(2), 122-148. http://dx.doi.org/10.1108/JLSS-122012-0014.

James-Moore, S. M., \& Gibbons, A. (1997). Is lean manufacture universally relevant? An investigative methodology. International Journal of Operations \& Production Management 17(9), 899-911. http://dx.doi.org/10.1108/01443579710171244.

Jasti, N. V. K., \& Kodali, R. (2016). An empirical study for implementation of lean principles in Indian manufacturing industry. Benchmarking, 23(1), 183-207. http://dx.doi.org/10.1108/BIJ-11-2013-0101.

Katayama, H., \& Bennett, D. (1996). Lean production in a changing competitive world: a Japanese perspective. International Journal of Operations \& Production Management, 16(2), 8-23. http://dx.doi.org/10.1108/01443579610109811.

Krafcik, J. (1988). Triumph of the lean production system. Sloan Management Review, 30(1), 41-52. Retrieved in 2018, July 29, from https://www.lean.org/downloads/MITSloan.pdf

Kundu, G., \& Murali Manohar, B. (2012). Critical success factors for implementing lean practices in IT support services. International Journal of Qualitative Research, 6(4), 301 312. Retrieved in 2018, July 29, from http://www.ijqr.net/journal/v6-n4/1.pdf

Leme, J. L., Tortorella, G. L., \& Augusto, B. P. (2016). Identification of barriers and critical success factors in lean implementation in micro-sized enterprises. Espacios, 37(5), 1 Retrieved in 2018, July 29, from https://www.researchgate.net/publication/303146759_Identification_of_ barriers_and_critical_success_factors_in_lean_implementation_in_micro-sized_enterprises

Li, J., Jovanovic, A., Klimek, P., \& Guo, X. (2015). Bibliometric analysis of fracking scientific literature. Scientometrics, 105(2), 1273-1284. http://dx.doi.org/10.1007/s11192-015-1739-7.

Liker, J. K. (2004). The Toyota way: 14 management principles from the world's greatest manufacturer. New York: McGraw-Hill.

Liker, J., \& Rother, M. (2011). Why Lean programs fail. Boston: Lean Enterprise Institute. Retrieved in 2017, October 24, from https://www.lean.org/Search/Documents/352.pdf

Liu, X., Zhang, L., \& Hong, S. (2011). Global biodiversity research during 1900-2009: a bibliometric analysis. Biodiversity and Conservation, 20, 807-826. http://dx.doi.org/10.1007/s10531-010-9981-z.

Mahmutaj, L. R., Jusufi, G., Zylfijaj, K., \& Grubi, A. K. (2015). The role of quality management practices in improving the efficiency and effectiveness of financial services. Mediterranean Journal of Social Sciences, 6(2), 218-225. http://dx.doi.org/10.5901/mjss.2015.v6n2s5p218. 
Mamat, R. C., Deros, B. M., Rahman, M. N. A., Omar, M. K., \& Abdullah, S. (2015). Soft lean practices for successful lean production system implementation in Malaysia automotive SMEs: a proposed framework. Jurnal Teknologi, 77(27), 141-150. Retrieved in 2018, July 29, from https://jurnalteknologi.utm.my/index.php/jurnalteknologi/article/view/6910/4587

Mann, D. (2005). Creating a Lean culture: tools to sustain lean conversion. New York: Productivity Press.

Manzouri, M., Nizam Ab Rahman, M., Saibani, N., \& Rosmawati Che Mohd Zain, C. (2013). Lean supply chain practices in the Halal food. International Journal of Lean Six Sigma, 4(4), 389-408. http://dx.doi.org/10.1108/IJLSS-10-2012-0011.

Marodin, G. A., \& Saurin, T. A. (2015). Classification and relationships between risks that affect lean production implementation: a study in southern Brazil. Journal of Manufacturing Technology Management, 26(1), 57-79. http://dx.doi.org/10.1108/JMTM-12-2012-0113.

McLean, R. S., Antony, J., \& Dahlgaard, J. J. (2017). Failure of Continuous Improvement initiatives in manufacturing environments: a systematic review of the evidence. Total Quality Management \& Business Excellence, 28(3-4), 219-237. http://dx.doi.org/10.1080/14783363.2015.1063414.

Mohammad, A., \& Mohd, N. (2015). Actualizing lean construction: barriers toward the implementation. Advances in Environmental Biology, 9(5), 172-174. Retrieved in 2018, July 29, from http://www.aensiweb.net/AENSIWEB/aeb/aeb/2015/April/172-174.pdf

Moyano-Fuentes, J., \& Sacristan-Diaz, M. (2012). Learning on lean: a review of thinking and research. International Journal of Operations \& Production Management, 32(5), 551-582. http://dx.doi.org/10.1108/01443571211226498.

Murman, E., Allen, T., Bozdogan, K., Cutcher-Gershenfeld, J., McManus, H., Nightingale, D., Rebentisch, E., Shields, T., Stahl, F., Walton, M., Warmkessel, J., Weiss, S., \& Widnall, S. (2002). Lean enterprise value: Insights from MIT's lean aerospace initiative. New York: Palgrave. http://dx.doi.org/10.1057/9781403907509.

Murugesan, T. K., Senthil Kumar, B., \& Saravana Kumar, M. (2012). Competitive advantage of World Class Manufacturing System (WCMS): a study of manufacturing companies in South India. European Journal of Soil Science, 29(2), 295-311. Retrieved in 2018, July 29, from https://www.researchgate.net/publication/265797666_Competitive_Advantage_of_World_C lass_Manufacturing_System_WCMS_-A_Study_of_Manufacturing_Companies. [in_South_India.]

Nahmens, I., \& Mullens, M. A. (2011). Lean homebuilding: lessons learned from a precast concrete panelizer. Journal of Architectural Engineering, 17(4), 155-161. http://dx.doi.org/10.1061/(ASCE)AE.1943-5568.0000037.

Näslund, D. (2013). Lean and six sigma: critical success factors revisited. International Journal of Quality and Service Sciences, 5(1), 86-100. http://dx.doi.org/10.1108/17566691311316266.

Netland, T. H. (2016). Critical Success Factors for implementing Lean production: the effect of contingencies. International Journal of Production Research, 54(8), 2433-2448. http://dx.doi.org/10.1080/00207543.2015.1096976.

Neumann, S. L., Mothersell, W. M., \& Motwani, J. (2015). The need for implementing lean in the public sector. International Journal of Business Excellence, 8(1), 104-121. http://dx.doi.org/10.1504/IJBEX.2015.065982.

Noori, B. (2015). Identifying critical issues in lean implementation in hospitals. Hospital Topics, 93(2), 44-52. http://dx.doi.org/10.1080/00185868.2015.1052299. PMid:26185933.

Ohno, T. (1997). Toyota production system: beyond large-scale production. Portland, OR: Productivity Press.

Osono, E., Norihiko, S., \& Takeuchi, H. (2008). Extreme Toyota: radical contradictions that drive success at the World's Best Manufacturer. Hoboken: John Wiley \& Sons. 
Pavnaskar, S. J., Gershenson, J. K., \& Jambekar, A. B. (2003). Classification scheme for lean manufacturing tools. International Journal of Production Research, 41(13), 3075-3090. http://dx.doi.org/10.1080/0020754021000049817.

Pedersen, E. R. G., \& Huniche, M. (2011). Determinants of lean success and failure in the Danish public sector: a negotiated order perspective. International Journal of Public Sector Management, 24(5), 403-420. http://dx.doi.org/10.1108/09513551111147141.

Phillips, J. F., Sheff, M., \& Boyer, C. B. (2015). The astronomy of Africa's health systems literature during the MDG era: where are the systems clusters? Global Health, Science and Practice, 3(3), 482-502. http://dx.doi.org/10.9745/GHSP-D-15-00034. PMid:26374806.

Poksinska, B. (2010). The current state of lean implementation in health care: literature review. Quality Management in Health Care, 19(4), 319-329. http://dx.doi.org/10.1097/QMH.0b013e3181fa07bb. PMid:20924253.

Rane, A. B., Sunnapwar, V. K., \& Rane, S. (2016). Strategies to overcome the HR barriers in successful lean implementation. International Journal of Procurement Management, 9(2), 223-247. http://dx.doi.org/10.1504/IJPM.2016.075266.

Rees, G. H. (2014). Organizational readiness and Lean Thinking implementation: findings from three emergency department case studies in New Zealand. Health Services Management Research, 27(1-2), 1-9. http://dx.doi.org/10.1177/0951484814532624. PMid:25595012.

Rose, A. N. M., Deros, B. M., \& Rahman, M. N. A. (2014). Critical success factors for implementing lean manufacturing in Malaysian automotive industry. Research Journal of Applied Sciences, Engineering and Technology, 8(10), 1191-1200. http://dx.doi.org/10.19026/rjaset.8.1084.

Rossiter Hofer, A., Hofer, C., Eroglu, C., \& Waller, M. A. (2011). An institutional theoretic perspective on forces driving adoption of lean production globally. International Journal of Logistics Management, 22(2), 148-178. http://dx.doi.org/10.1108/09574091111156532.

Sahwan, M. A., Ab Rahman, M. N., \& Deros, B. M. (2012). Barriers to implement lean manufacturing in Malaysian automotive industry. Jurnal Teknologi, 59(2), 107-110. http://dx.doi.org/10.11113/jt.v59.2571.

Scherrer-Rathje, M., Boyle, T., \& Deflorin, B. (2009). Lean, Take Two! Reflections from the Second Attempt at Lean Implementation. Business Horizons, 52(1), 79-88. http://dx.doi.org/10.1016/j.bushor.2008.08.004.

Schuh, G., Potente, T., Bachmann, F., \& Nuyken, T. (2012). Lean management in indirect areas: change of company culture supported by methods. Zeitschrift fuer Wirtschaftlichen Fabrikbetrieb, 107(6), 399-403. http://dx.doi.org/10.3139/104.110776.

Sim, K. L., \& Rogers, J. W. (2008). Implementing lean production systems: barriers to change. Management Research News, 32(1), 37-49. http://dx.doi.org/10.1108/01409170910922014.

Simões, V. (2008). Critical factors of lean implementation in manufacturing envoronments (Dissertação de mestrado). Faculdade de Engenharia, Universidade do Porto, Portugal.

Sisson, J., \& Elshennawy, A. (2015). Achieving success with Lean. International Journal of Lean Six Sigma, 6(3), 263-280. http://dx.doi.org/10.1108/IJLSS-07-2014-0024.

Souza, L. B., \& Pidd, M. (2011). Exploring the barriers the lean health care implementation. Public Money \& Management, 31(1), 59-66. http://dx.doi.org/10.1080/09540962.2011.545548.

Vinodh, S., \& Joy, D. (2012). Structural equation modelling of lean manufacturing practices. International Journal of Production Research, 50(6), 1598-1607. http://dx.doi.org/10.1080/00207543.2011.560203.

Wincel, J., \& Kull, T. (2013). People, process, and culture: lean manufacturing in the real world. New York: CRC Press. 
Womack, J., Jones, D., \& Ross, D. (1990). The machine that changed the world. New York, NY: Rawson Associates.

Worley, J. M., \& Doolen, T. L. (2015). Organizational structure, employee problem solving, and lean implementation. International Journal of Lean Six Sigma, 6(1), 39-58. http://dx.doi.org/10.1108/IJLSS-12-2013-0058.

Zhou, B. (2016). Lean principles, practices, and impacts: study on small and medium-sized enterprises (SMEs). Annals of Operations Research, 241(1-2), 457-474.

http://dx.doi.org/10.1007/s10479-012-1177-3. 
Appendix 1. Bibliometric Analysis of the ten most cited articles in the period from 2006 to 2017.

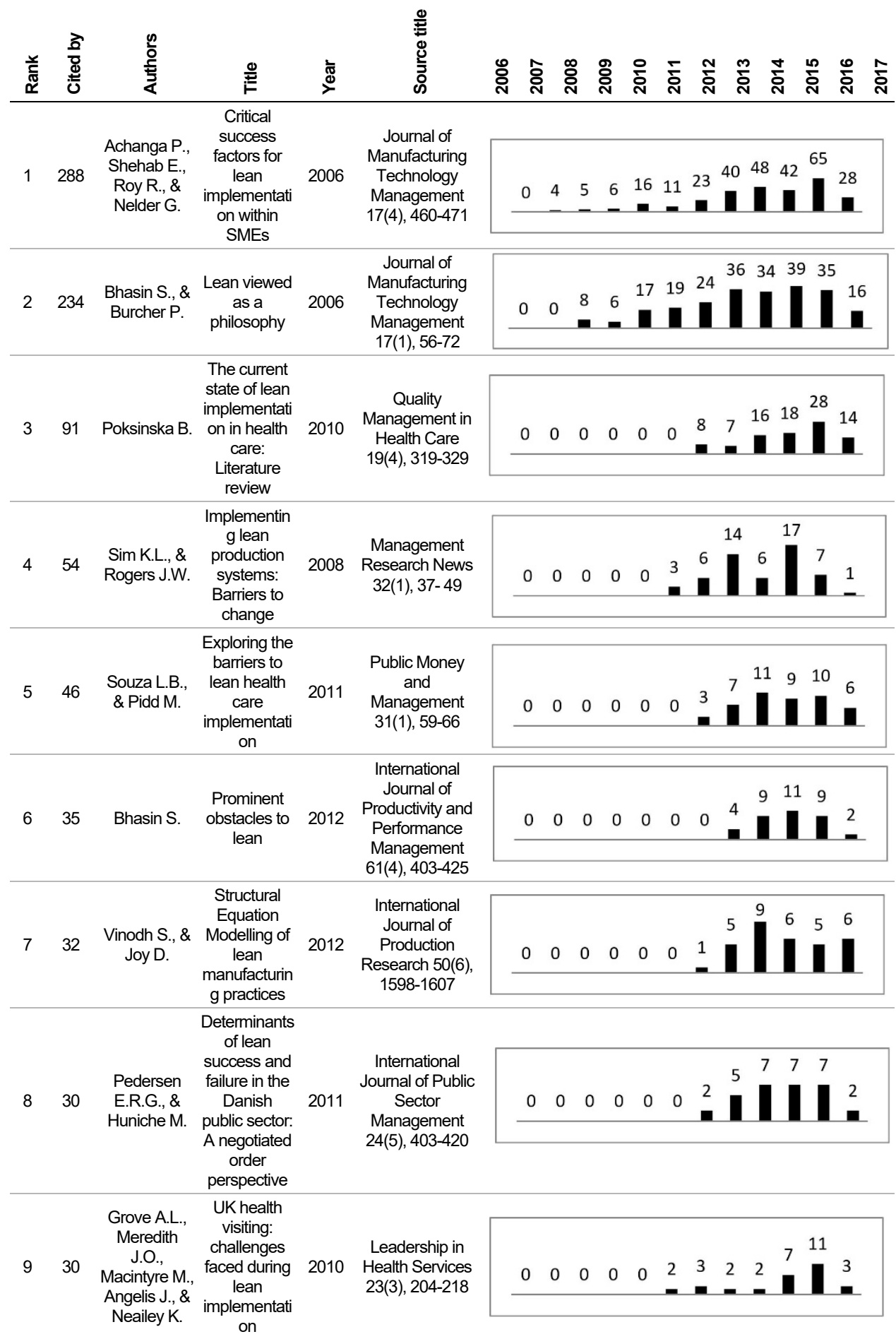




\begin{tabular}{|c|c|c|c|c|c|c|c|c|c|c|c|c|c|c|c|c|c|c|c|}
\hline 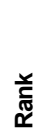 & 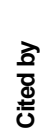 & $\begin{array}{l}\frac{00}{0} \\
\frac{0}{5} \\
\frac{3}{4}\end{array}$ & $\stackrel{\Phi}{\stackrel{\Xi}{F}}$ & ঠ্ঠ & 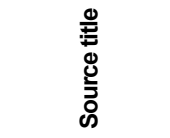 & ণั่ & ఫิ & ఫి సి & & సั. & 울 & స్. & సั & $\stackrel{m}{\text { i }}$ & & ปั่ & ำ & $\stackrel{\circ}{\text { ஸे }}$ & సิ \\
\hline 10 & 22 & $\begin{array}{c}\text { Dora M., van } \\
\text { Goubergen } \\
\text { D., Kumar } \\
\text { M., Molnar } \\
\text { A., \& } \\
\text { Gellynck X. }\end{array}$ & $\begin{array}{l}\text { Application of } \\
\text { lean } \\
\text { practices in } \\
\text { small and } \\
\text { medium- } \\
\text { sized food } \\
\text { enterprises }\end{array}$ & 2014 & $\begin{array}{c}\text { British Food } \\
\text { Journal 116(1), } \\
\text { 125-141 }\end{array}$ & & 0 & 0 & 0 & 0 & 0 & 0 & 0 & 0 & 0 & 7 & 6 & & \\
\hline
\end{tabular}

